\title{
Omphalocele: a review of common genetic etiologies
}

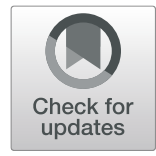

\author{
Henriette Poaty ${ }^{1 *}$, Fanny Pelluard ${ }^{2}$, Mama Sy Diallo ${ }^{3}$, Irène Patricia Lucienne Ondima ${ }^{1,4}$, Gwenaelle André ${ }^{2}$ and \\ Jacques François Silou-Massamba ${ }^{5}$
}

\begin{abstract}
Omphalocele is one of the most common congenital defects in the anterior abdominal wall. The malformation is associated with various pathologies especially with chromosomal disorders. The developmental defect is observed in Congolese hospitals, but risk factors are not well precised on the published case reports, which are more often focused on management. We aim in this paper to make a review on the condition, insisting on the risk factors of omphaloceles mainly of those of genetic origins.
\end{abstract}

Keywords: Omphalocele, Abdominal wall defect, Genetic disorders, Congenital malformation

\section{Background}

Omphalocele, also called exomphalos, is a congenital malformation due to a defect in closure of the anterior abdominal wall [1-3]. This leads to midline herniation of the abdominal viscera covered by a membranous sac, into the base of the umbilical cord insertion $[1,4,5]$.

It is a rare and serious condition. However, it is one of the most common anterior abdominal wall defects [6]. As the defect is observed in the Congolese fetuses or newborn babies, the purpose of this review is to clarify the main genetic risk factors associated with the omphalocele. This review is imaged by three omphalocele cases originated from Congo and France (Figs. 1 and 2). The Congolese cases: a newborn (with isolated omphalocele) (Fig. 1a) and one fetus (with trisomy 13) (Fig. 2a) have been examined respectively in the department of Surgery Paediatrics of Brazzaville's teaching hospital (TH) and in the Genetics Unit of the Health Sciences Faculty of Brazzaville. The French fetus (with trisomy 13) (Figs. 1b and 2b) has been examined in Department of Fetopathology of Pellegrin's TH (Bordeaux, France).

\footnotetext{
*Correspondence: henriettepoaty@gmail.com

'Histology-Embryology and Genetic Laboratory, Faculty of Health Sciences,

University Marien Ngouabi, BP 2672, Brazzaville, Congo

Full list of author information is available at the end of the article
}

\section{Main text}

Embryologic origin

Embryologically, omphalocele is an embryopathy resulting from an error in a midline abdominal wall development in early embryonic development (ED). Indeed, the normal development of the primitive intestine allows at 6 weeks of ED a normal physiologic herniation of the primitive mid-gut after undergoing the 90 degrees counterclockwise rotation back into the umbilical cord [7]. The mid-gut protrudes from the abdominal cavity (which is too small to contain it) into the umbilical cord $[2,7]$. In the normal state, at the age of 10 until 11 weeks of ED, the primitive mid-gut undergoes again the 180 degrees counterclockwise rotation and returns completely into the abdominal cavity from the yolk sac. The physiologic hernia disappears with complete closure of the umbilical ring $[7,8]$.

At the origin of the omphalocele, one incriminates two failures [8]: (i) an incomplete embryonic lateral plicature between 4 and 8 weeks of ED. The two lateral folds (right and left) of mesoderm (at the origin of the serous membrane of organism) do not close at the site of umbilical insertion. (ii) An incomplete migration and differentiation of mesodermal somites into myotomes from which originate cutaneous tissue and abdominal wall muscles [8]. This leads to an incomplete closure of umbilical ring. The mid-gut fails the rotation and do not return into the abdominal cavity. The fetal bowels and 

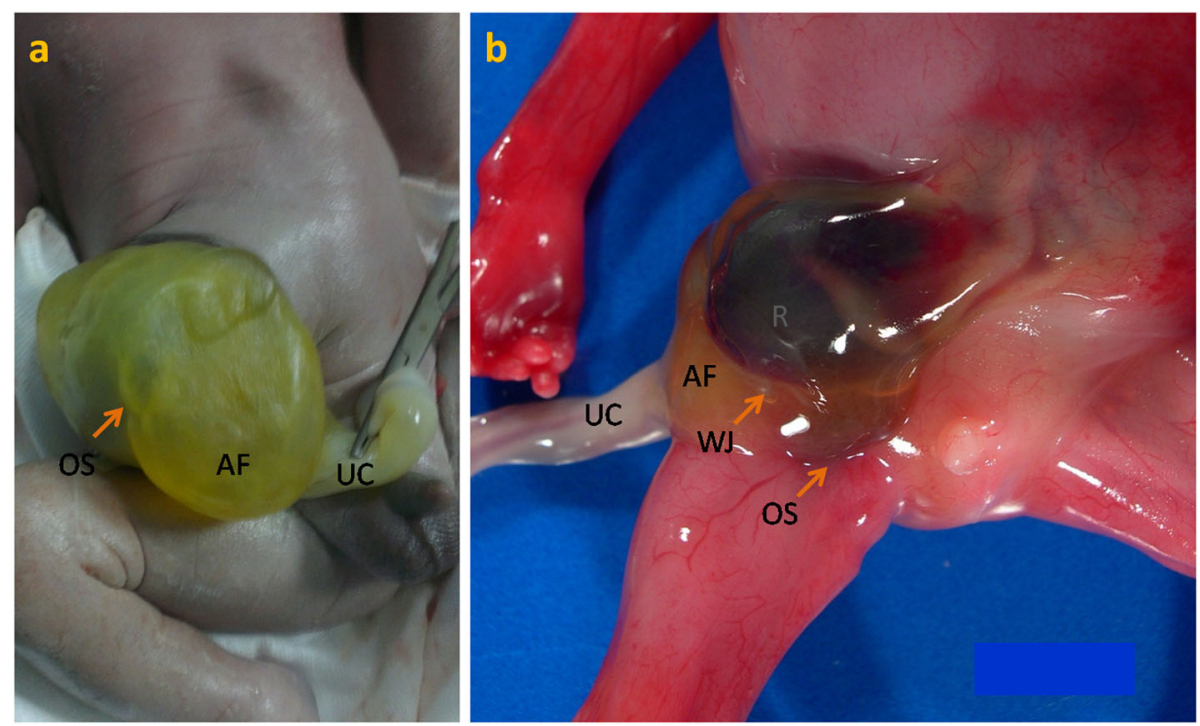

Fig. 1 Intact central omphalocele. a Isolated omphalocele in male liveborn Congolese infant (before surgery): medium-sized omphalocele covered with a thin sac (OS) of membrane containing the amniotic fluid (AF, yellow) and the intestines. Umbilical cord (UC) inserted into the omphalocele. b Omphalocele in male French Fetus: medium-sized omphalocele (os) containing the spleen (R), covered with a translucent sac of fused membrane of amnion, peritoneum and the Wharton's jelly between the membranes. Umbilical cord inserted into the omphalocele

other abdominal organs protrude through the opening, giving the omphalocele (Figs. 1 and 2).

We note that the abdominal wall defects may occur in different locations during embryogenesis, showing the full complexity of the condition. In fact, there are three classes of omphaloceles based on the site of the defect and umbilical cord insertion [9]: (i) epigastric (or cranial) omphaloceles, concern the upper abdominal wall and do not reach the umbilicus. The most severe form is the pentalogy of Cantrell. (ii) Central omphaloceles, concern the middle abdominal wall and are periumbilical. They are the most common. (iii) Hypogastric (or caudal)
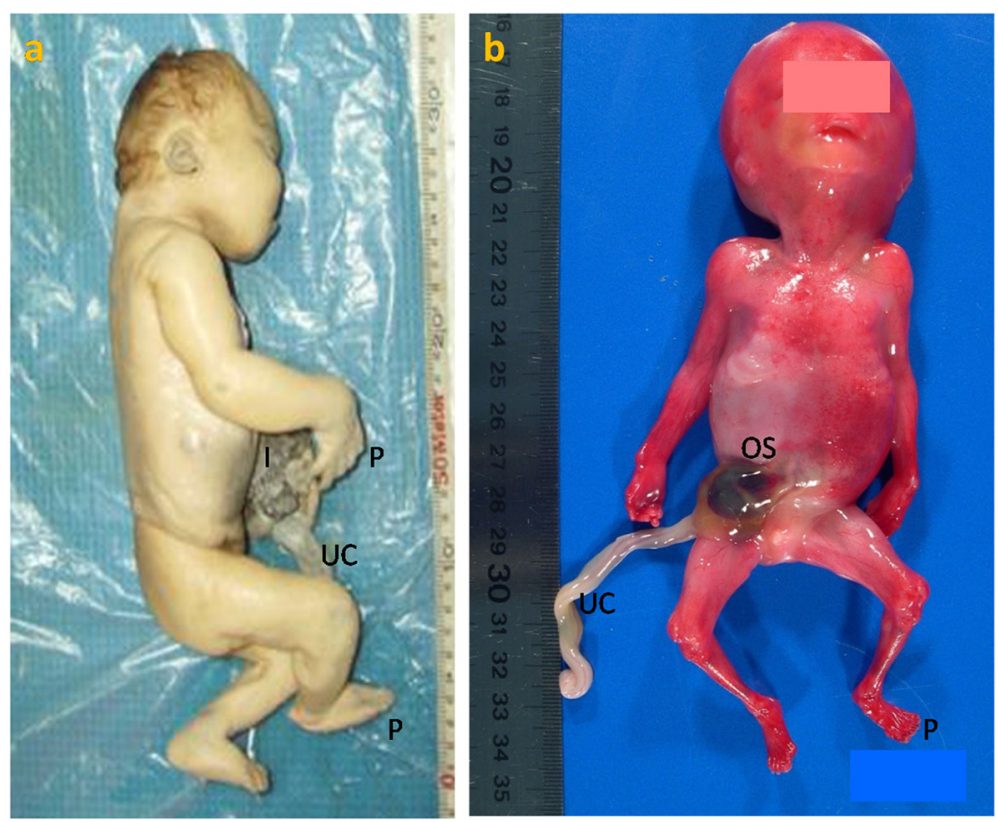

Fig. 2 Omphalocele in fetuses with trisomy 13. a Male Congolese fetus born dead. Ruptured omphalocele (o) with eviscerated small intestines (i) and umbilical cord (UC) inserted in the omphalocele. Dysmorphic facies with microcephaly, cleft lip, ears down inserted. Bilateral postaxial polydactyly (P) of hands and feet. b Male French fetus after termination of pregnancy. Intact omphalocele (o), dysmorphic facies with microcephaly, cleft palate, low set ears, postaxial hexadactyly of hands and feet 
omphaloceles, concern the lower abdominal wall, under the umbilicus and are always associated with urorectal anomalies.

\section{Epidemiology}

The prevalence of omphalocele is variable according to the series and the country. The approximate prevalence is in the range of 1:4000 to 1:7000 live births $[4,9,10]$. The large American and French cohort omphaloceles have given respectively a mean prevalence rate of 1.92 and 2.18 per 10,000 live births predominant in male neonates $[11,12]$. Compared with congenital malformations, in Morocco, the prevalence rate of reported omphalocele was $1 \%$ of congenital malformations for a period of 8 years [5]. In Congo, the medical records of 430 congenital malformations seen in Pediatric services of $\mathrm{TH}$ for a period of 5 years showed four omphalocele cases in liveborn infants, i.e., a prevalence of $0.93 \%$ of congenital malformations. The male to female sex ratio was 1:1.

\section{Diagnosis and content}

Imaging allows the identification of omphalocele from early antenatal period, by the fetal ultrasound screening (in $67.2 \%$ of cases) in the first and second trimesters (since the gestational age 12-14 weeks and later) or by resonance magnetic imaging (RMI), computed tomography scan and by abdominal X-ray in neonates [1, 4, 13-15].

The maternal serum alpha-fetoprotein and the dosage of acetylcholinesterase in the amniotic fluid are used in antenatal period for omphalocele screening. The tests can reveal an elevated level of those biomarkers $[1,5]$. Genetic analysis (for etiological research) is recommended, especially karyotype and or chromosomal microarray.

The omphalocele images are characteristic (Fig. 1a, b): the hernia containing the abdominal viscera embedded in amniotic fluid is covered by a thin sac of fused membranes of amnion (externally) and peritoneum (internally), with the Wharton's jelly between the two components $[1,4,6,9]$. The umbilical cord is abnormally inserted into the omphalocele sac [15]. The eviscerated organs are predominantly intestines (illustrated by Fig. 2a), liver or spleen and pancreas as observed in one our fetuses (Figs. $1 \mathrm{~b}$ and $2 \mathrm{~b}$ ), rarely colon, ovaries or stomach $[1,5,14]$.

\section{Associated congenital anomalies}

Omphalocele is sometimes associated with other congenital malformations which increase the newborns mortality and the defect seems to be more prevalent in male gender. The prevalence of associated anomalies is in 31 to $50 \%$ of omphaloceles or more (63 to $80 \%$ ) according to the series $[6,10,13,16-18]$. These additional anomalies are various, and all organs can be affected depending on the etiology [19]. They can be: neural tube defects (anencephaly, holoprosencephaly, spina bifida and rudimentary orbits), cleft palate, single umbilical artery, amniotic fluid anomaly (oligoamnios or polyhydramnios) [6, 20]. Other associated anomalies include cardiovascular defects (the most common up to $40 \%$ ), digestive (like Meckel's diverticulum), metabolic, musculoskeletal or urogenital anomalies (for example micropenis and multicystic kidneys) [2, 4, 11, 13, 16, 21]. In regard to these associated anomalies, a fetopathological examination (for the fetuses) and a complete clinical examination of the neonate are needed.

\section{Genetic origins}

Genetic diseases and polymalformative syndromes are commonly diagnosed in fetuses and neonates with omphalocele. In the most cases (28 to 50\%), omphaloceles are isolated and are considered as sporadic and weakly recurrent [22-24]. In most cases (more than 50\%), the malformation is linked to various pathologies and can be a call sign of genetic disorders [9, 16]. Genetic risk factors are the commonest one: firstly chromosomal aberrations, secondly genetic syndromes, and thirdly polymalformative syndromes. In addition, several genes are related to omphalocele.

\section{Chromosomal aberrations}

They are involved in 38 to $67 \%$ of the omphaloceles, mainly the aneuploidies $[2,9,25]$. The most frequent are as follows: trisomy 18 which ranks the first place (22 to $89 \%$ of fetuses having omphalocele) and trisomy 13 which clinical features are represented by Fig. 2 (trisomy confirmed by the karyotype not shown) [9, 15, 26, 27]. The data compilation of the chromosomal anomalies from literature (Table 1) gives the average incidence of $77.2 \%$ for trisomy 18 and of $11.4 \%$ for trisomy 13 , in coherence with the published data. It may be noted that chromosomal anomalies are more associated with central omphalocele [9]. Other chromosomal aberrations that can be identified are for instance: triploidy; monosomy X (Turner syndrome); 47, XXY (Klinefelter syndrome); trisomy 16 and 21 (very low contributors); partial trisomy such as dup (1q), dup (3q), dup (4q), dup (5p), dup (6q), dup (11p), dup (15q23), dup (17q) or deletion like del (1q), del (9p); inv (11) [14, 16, 29-31].

\section{Genetic syndromes}

Familial syndromal forms of omphalocele over two generations (requiring genetic counseling) are reported $[23,24,32]$. The mode of inheritance can be autosomal dominant, autosomal recessive or X-linked trait [3, 24, 32]. The most common syndrome is the Beckwith-Wiedemann syndrome (BWS), seen in 3 to $22 \%$ of omphaloceles $[4,22,27]$. BWS is a paternal uniparental disomy (UPD) of $11 \mathrm{p} 15$ imprinted region, inherited in autosomal 
Table 1 Median incidence of common chromosomal anomalies in omphalocele

\begin{tabular}{llllllllll}
\hline No. & $\%$ CA & Trisomy 18 & Trisomy 13 & Trisomy 21 & Triploidy & TS & KS & Others & Authors \\
\hline 90 & $48.9(44 / 90)$ & 33 & 5 & 1 & 2 & 1 & - & 2 & Brantberg et al., 2005 [9] \\
26 & $38(10 / 26)$ & 4 & 4 & 1 & - & 1 & - & - & Nyberg et al., 1989 [25] \\
67 & $39(26 / 67)$ & 21 & 2 & 1 & - & 1 & - & 1 & Fratelli et al., 2007 [26] \\
35 & $34(12 / 35)$ & 10 & 2 & 0 & - & - & - & - & Emer et al., 2015 [28] \\
35 & $54(19 / 35)$ & 17 & - & - & 1 & - & 1 & - & Chen et al., 2007 [29] \\
18 & $67(12 / 18)$ & 10 & 1 & - & 1 & - & - & - & Chen et al., 2007 [29] \\
271 & $(n=123) 45.4$ & $9577.2 \%$ & $1411.4 \%$ & $32.4 \%$ & $43.25 \%$ & $32.4 \%$ & $10.8 \%$ & $32.4 \%$ & \\
\hline
\end{tabular}

No., number of omphalocele; $C A$, chromosomal abnormalities; $n$, number of $C A ; S$, syndrome; $T$, Turner; $K$, Klinefelter

recessive manner. The latter condition associates the following clinical features: polyhydramnios, macrosomia, macroglossia, visceromegaly, abdominal wall defect, external ear abnormalities and hypoglycemia (to the neonate) $[4,9,29]$. Paternal UPD of $14 q 32$ imprinted region has been also reported. It concerns Kagami-Ogata syndrome inherited on autosomal dominant mode. The clinical signs include: a characteristic facies, small thorax, abdominal wall defects, placentomegaly and polyhydramnios (OMIM \# 608149) [33]. Other genetic syndromes associated with omphalocele are for instance: Miller-Dieker lissencephaly syndrome (microcephaly, lissencephaly, small brain, deletion on 17p13.3 band inherited on autosomal dominant mode); Pallister-killian syndrome (coarse dysmorphic facies, mental retardation, skin anomalies, tetrasomy 12p); Meckel-Grumber (occipital encephalocele, postaxial polydactyly, multicystic dysplastic kidneys, inherited on autosomal recessive mode); Goltz syndrome (X-linked dominant trait) and Marshallsmith syndrome [13, 29, 30].

\section{Polymalformative syndromes}

Omphalocele may be a part of morbid polymalformative syndromes (PS), recurrent in some families. Among them are the OEIS complex (3\% of omphaloceles) which is a combination of the following defects: hypogastric omphalocele, exstrophy of bladder, imperforate anus and spina bifida) [13, 22, 34]. Deletion of 1p36 has been described (OMIM \# 258040). Another PS is the pentalogy of Cantrell which associates an epigastric omphalocele, a diaphragmatic hernia, an agenesis or a bifid sternum, a cardiac ectopia (or ectopia cordis) and an intra-cardiac defect $[4,5,28,35]$. The condition can be inherited in $\mathrm{X}$-linked dominant mode in the region Xq25-q26.1 (OMIM \# 313850); Familial cases of Prune Belly (EagleBarrett syndrome) inherited in autosomal recessive manner have been reported and the chromosome regions identified were 1q41-q44 and 11p11 (OMIM \# 100100). The phenotype includes: abdominal muscle deficiency, cryptorchidism and urinary tract malformation, is also associated with omphalocele [19].
Generally, omphaloceles originating from genetic origins are small (with often an intestinal content) and associated anomalies are more frequent $[1,9,25,30]$. Their prognosis especially in presence of additional malformations or chromosomal aberrations is less good than in isolated omphaloceles [2, 9, 11, 27].

\section{Gene mutations}

Several genes (MalaCards 2019, 2013 GRCh38/hg38) are indexed in the occurrence of omphalocele, among which CDKN1C (cyclin dependent kinase inhibitor 1C) or P57kip2, an imprinted gene with maternal expression, mapped on 11p15.4 imprinted region. The gene is involved in cell cycle and acts as negative regulator of cell proliferation. CDKN1C mutation causes BWS associated with omphalocele [36]. Alx4 (Aristaless-like Homeobox 4) located on 11p11.2 chromosomal band, belongs to the homeobox family. It plays an essential role in skeletal and skin development and it is high expressed in skeletal and smooth muscles. Disorder in Alx4 causes omphalocele in mice [37]. FGFR1 and FGFR2 (fibroblast growth factor receptors 1 and 2) are thyrosine protein kinase respectively located on $8 \mathrm{p} 11.23$ and 10q26.13. They play a role in the regulation of embryonic development and are expressed in ectoderm of the abdominal wall. Their conditional both mutation also results in an omphalocele in mice [38]. We have in Table 2 reported other susceptibility genes for omphalocele (MalaCards 2019; 2013 GRCh38/hg38) [31, 39, 40].

We can also mention that it exists other causes than genetics, indexed in the occurrence of omphalocele, for instance: consanguineous parents, obesity, maternal age (young or advanced), multiple gestation, water soluble vitamins and cofactors (folic acid, vitamins B complex), environmental factors, intake by the mother of antithyroid drugs, antiepileptic (valproic acid) and alcohol (Mala Cards 2019) [1, 5, 11, 41].

\section{Differential diagnosis and treatment}

The differential diagnosis of omphalocele is mainly made with the following: (i) the gastroschisis: it is a herniation of intestinal structures, right para-umbilical, not covered 
Table 2 Genes related to omphalocele (MalaCards 2019; 2013 GRCh38/hg38)

\begin{tabular}{|c|c|c|c|}
\hline Genes & Location & Activity & References \\
\hline $\begin{array}{l}\text { PLOD1 (Procollagen-lysine, 2-oxoglutarate } \\
\text { 5dioxygenase1) }\end{array}$ & 1 p36.22 & $\begin{array}{l}\text { Epidermis development, stability of the intermolecular collagen } \\
\text { cross-links. } \\
\text { high expressed in skeletal and smooth muscle }\end{array}$ & $\begin{array}{l}\text { Tosun et al., } 2014 \\
\text { [39] }\end{array}$ \\
\hline Msx1 (Msh homeobox 1) & $4 p 16.2$ & \multirow{2}{*}{$\begin{array}{l}\text { Embryonic morphogenesis, multicellular organism development. } \\
\text { Regulation of cellular proliferation and differentiation }\end{array}$} & \multirow{2}{*}{$\begin{array}{l}\text { Doi et al., } 2010 \\
{[40]}\end{array}$} \\
\hline Msx2 (Msh homeobox 2) & $5 q 35.2$ & & \\
\hline $\begin{array}{l}\text { NUAK1 (SNF1-like kinase, 1) } \\
\text { Omphalocele kinase } 1\end{array}$ & $12 q 23.3$ & \multirow[t]{2}{*}{$\begin{array}{l}\text { Regulation of cell adhesion and cell proliferation. Expressed in } \\
\text { heart, brain, skeletal and smooth muscle }\end{array}$} & \multirow[t]{2}{*}{$\begin{array}{l}2013 \text { GRCh38/ } \\
\text { hg38 }\end{array}$} \\
\hline $\begin{array}{l}\text { NUAK2 (SNF1-like kinase, 2) } \\
\text { Omphalocele kinase } 2\end{array}$ & $1 q 32.1$ & & \\
\hline GJB2 (Gap Junction Beta-2 Protein) & $13 q 12.11$ & $\begin{array}{l}\text { Connexin family. Cell communication expressed in the suprabasal } \\
\text { layer of the epidermis. }\end{array}$ & $\begin{array}{l}\text { Zhou et al., } 2018 \\
\text { [31] }\end{array}$ \\
\hline GLCE (D-glucuronyl C5-epimerase) & $15 q 23$ & Highly expressed in the digestive tract and the skin & $\begin{array}{l}\text { Zhou et al., } 2018 \\
\text { [31] }\end{array}$ \\
\hline RPLP1 (ribosomal protein lateral stalk subunit P1) & $15 q 23$ & $\begin{array}{l}\text { Structural constituent of ribosome, activator of protein kinase } \\
\text { activity }\end{array}$ & $\begin{array}{l}\text { Zhou et al., } 2018 \\
\text { [31] }\end{array}$ \\
\hline
\end{tabular}

by a membranous sac, and the umbilical cord is normally inserted in the abdominal wall [1, 3]; (ii) umbilical hernia: consists in a slippage of the digestive tract in the umbilical cord and it is skin covered [3,5]. (iii) The persistence of the physiological gut herniation: it is small (inferior to $7 \mathrm{~mm}$ of diameter) and exceeds 12 weeks of ED [5].

Concerning the treatment, the condition is a medical and surgical emergency when the newborn is alive and is depending on the size of the defect. Two types of surgical closures are proposed: primary closure (just after birth) for small-sized omphaloceles and delayed closure (later) for giant omphaloceles $[2,6,10]$.

\section{The prognosis}

The associated congenital anomalies, the ruptured sac and the size of omphalocele determine the prognosis of the newborn. Omphaloceles are classified as small or giant defect and there are many anatomic classifications that determine the prognosis. The most used is Aitken classification (Table 3), and the type I (small-sized defects, inferior to $4 \mathrm{~cm}$ ) have excellent results with the survival rates of 90 to $97 \%$, if they are isolated $[5,6,9,21]$. Ndour et al. [19] reported in their series an overall mortality rate of $45.3 \%$

Table 3 Omphalocele Aitken classification

\begin{tabular}{ll}
\hline Type & Criteria \\
\hline & Larger of defect (collar base) $<4 \mathrm{~cm}$ \\
& Diameter of the $\mathrm{sac}<8 \mathrm{~cm}$ \\
& Absence of liver \\
& Collar base $>5 \mathrm{~cm}$ \\
& Diameter of the sac $>8 \mathrm{~cm}$ \\
& Presence of the liver in the sac
\end{tabular}

Type I: all criteria must be present

Type II: presence of one criterion is sufficient (less prevalent in isolated defects). In one Nigerian study, omphalocele accounted for $18.3 \%$ of the neonatal surgical pathology and the rate post-operative mortality was of $26 \%$, while it was of $15 \%$ in one Moroccan published study $[5,42]$. A new insight for the type II giant omphaloceles (defects greater than $5 \mathrm{~cm}$ or presence of liver) is the possible conservative management at birth with delayed surgical closure of the ventral hernia after [10]. Topical agents are used before, to promote escharification and epithelialization of the omphalocele sac $[10,21]$. The therapeutic approach seems to be controversial (it can reduce the mortality rates in some cases and can increase mortality rates in other cases.

\section{Conclusion}

This paper mainly based on a review, shows than genetic disorders; predominantly chromosomal aberrations (aneuploidies) are providers of omphalocele. So fetal or neonate karyotyping is recommended in the latter. The additional congenital anomalies, familial omphalocele history, and advanced maternal age (indexed in the occurrence of aneuploidy) may alert the clinicians in the search of a genetic disease which can necessitate genetic counseling in inherited and recurrent cases.

\section{Abbreviations}

AF: Amniotic fluid; BWS: Beckwith-Wiedemann syndrome; del: Deletion; dup: Duplication; ED: Embryonic development; i: Intestines;

OEIS: Omphalocele, exstrophy, imperforate, spina bifida; OS: Omphalocele sac; P: Polydactyly; PS: Polymalformative syndrome; RMI: Resonance magnetic imaging; TH: Teaching hospital; UC: Umbilical cord; UPD: Uniparental disomy

\section{Acknowledgements \\ We would like to thank the patient families and clinicians who provided the photos.}

\section{Authors' contributions}

All authors have contributed to write this paper. They have read and approved the final manuscript. 


\section{Funding}

Not applicable.

\section{Availability of data and materials}

Not applicable

Ethics approval and consent to participate

Not applicable

\section{Consent for publication}

Obtained.

\section{Competing interests}

The authors declare that they have no competing interests.

\section{Author details}

${ }^{1}$ Histology-Embryology and Genetic Laboratory, Faculty of Health Sciences, University Marien Ngouabi, BP 2672, Brazzaville, Congo. ${ }^{2}$ Department of Fetopathology, CHU Pellegrin, Place Amélie Raba, 33076 Bordeaux cedex, France. ${ }^{3}$ Histology-Embryology and Cytogenetic Laboratory, Faculty of Medicine, Cheikh Anta Diop University, Dakar, Senegal. ${ }^{4}$ Department of Surgery Paediatrics, University Teaching Hospital Center, Brazzaville, Congo.

${ }^{5}$ Clinique Mère et Enfant, Brazzaville, Congo.

Received: 9 August 2019 Accepted: 5 November 2019

Published online: 27 December 2019

\section{References}

1. Campbell KH, Copel JA. Omphalocele. Obstetric imaging: fetal diagnosis and Care. 2ed, Elsevier, Philadelphia; 2018. p. 85-91.

2. Lamquami S, Mamouni N, Errarhay S, Bouchikhi C, Banani A (2015) Antenatal diagnosis of isolated omphalocele. Pan Afri Med J 21:233

3. Kilby MD, Lander A, Usher SM (1998) Exomphalos. Prenat Diagn 18:1283-1288

4. Kominiarek MA, Zork N, Pierce SM, Zollinger T (2011) Perinatal outcome in the liveborn infant with prenatally diagnosed omphalocele. Am J Perinatol 28:627-634

5. Garmane A. Omphalocèle : diagnostic et traitement. Thèse $N^{\circ} 175,29$ juin 2017, Marrakech 2017

6. Rattan KN, Singh J, Jakhar R, Dalal P, Sonika P (2018) Omphalocele: 15-years experience from a single center in developing country. J Clin Neonatol 7:125-129

7. Mitchell B, Sharma R (2005) Embryologie. Elsevier, Paris

8. Larsen. Embryologie Humaine. $2^{\text {ème }}$ ed, de boeck, Paris; 2003. p. 251-252.

9. Brantberg A, Blaas HG, Haugen SE, Eik-Nes SH (2005) Characteristics and outcome of 90 cases of fetal omphalocele. Ultrasound Obstet Gynecol 26:527-537

10. El Ezzi O, Boussou R, Reinberg O, Vasseur Maurer S, de Buys Roessingh A (2017) Delayed closure of giant omphaloceles in West Africa: report of five cases. Eur J Pediatr Surg Rep 5:e4-e8

11. Marshall J, Salemi JL, Tanner JP, Ramakrishnan R, Feldkamp ML, Marengo LK et al (2015) National Birth Defects Prevention Network. Prevalence, correlates, and outcomes of omphalocele in the United States, 1995-2005. Obstet Gynecol 126:284-293

12. Stoll C, Alembik Y, Dott B, Roth MP (2001) Risk factors in congenital abdominal wall defects (omphalocele and gastroschisi): a study in a series of 265,858 consecutive births. Ann Genet 44:201-208

13. Stoll C, Alembik Y, Dott B, Roth MP (2008) Omphalocele and gastroschisis and associated malformations. Am J Med Genet A 146A:1280-1285

14. Ayachi A, Mourali M (2016) Prenatal diagnosis of omphalocele in a woman in the first trimester of pregnancy. Pan Afri Med J 25:187

15. Deschamps F, Faure JM. Des malformations congénitales du fœtus. Altas échographique. Sauramps médicale, Montpellier; 1998. p. 223.

16. Muataz A, Ani A, Ali Khan SA (2014) Omphalocele with Intra Abdominal Anomalies. J Neonatal Surg 3:3

17. Abdur-Rahman LO, Abdulrasheed NA, Adeniran JO (2011) Challenges and outcomes of management of anterior abdominal wall defects in a Nigerian tertiary hospital. Afr J Paediatr Surg 8:159-163

18. Heider AL, Strauss RA, Kuller JA (2004) Omphalocele: clinical outcomes in cases with normal karyotypes. Am J Obstet Gynecol 190:135-141

19. Ndour O, Faye Fall A, Alumeti DM, Fall M, Diouf C, Ndoye A, et al. Etude des facteurs pronostiques de l'omphalocèle au service de Chirurgie Pédiatrique du CHU Aristide Le Dantec de Dakar : A propos de 95 cas. Rev. CAMES 2009; Série A (08) : 103-106.
20. Waghmare TP, Sathe PA, Goel NA, Kandalkar BM (2016) Alobar holoprosencephaly associated with meningomyelocoele and omphalocoele: an unusual coexistence. J Clin Diagn Res 10:ED23-ED24

21. Kouamé BD, Dick RK, Ouattara O, Traoré A, Gouli JC, Dieth AG et al (2003) Approches thérapeutiques des omphalocèles dans les pays en développement : I'expérience du CHU de Yopougon, Abidjan. Côte d'Ivoire Bull Soc Pathol Exot 96:30-305

22. Roux N, Grangé G, Salomon ப, Rousseau V, Khen-Dunlop N, Beaudoin S (2019) Early diagnosis of omphalocele: prognostic value of the herniated viscera for associated anomalies. Gynecol Obstet Fertil Senol 47:637-642

23. Port-Lis M, Leroy C, Manouvrier S, Escande F, Passemard S, Perrin L, Capri Y, Gérard B, Verloes A (2011) A familial syndromal form of omphalocele. Eur J Med Genet 54:337-340

24. Kanagawa SL, Begleiter ML, Ostlie DJ, Holcomb G, Drake W, Butler MG (2002) Omphalocele in three generations with autosomal dominant transmission. J Med Genet 39:184-185

25. Nyberg DA, Fitzsimmons J, Mack LA, Hughes M, Pretorius DH, Hickok D, Shepard TH (1989) Chromosomal abnormalities in fetuses with omphalocele. Significance of omphalocele contents. J Ultrasound Med 8:299-308

26. Fratelli N, Papageorghiou AT, Bhide A, Sharma A, Okoye B, Thilaganathan B (2007) Outcome of antenatally diagnosed abdominal wall defects. Ultrasound Obstet Gynecol 30:266-270

27. Watanabe S, Suzuki T, Hara F, Yasui T, Uga N, Naoe A (2017) Omphalocele and gastroschisis in newborns: over 16 years of experience from a single clinic. J Neonat Surg 6:27

28. Emer CS, Duque JA, Müller AL, Gus R, Sanseverino MT, da Silva AA, et al. (2015) Prevalence of congenital abnormalities identified in fetuses with 13, 18 and 21 chromosomal trisomy. Rev Bras Ginecol Obstet 37: 333-8

29. Chen CP (2007) Chromosomal abnormalities associated with omphalocele. Taiwan J Obstet Gynecol 46:1-8

30. Chen CP. Prenatal diagnosis and genetic counseling of omphalocele. An overview and altas of cases. Elsevier, Taiwan LLC; 2008. p: 1-26.

31. Zhou HF, O'Conor CJ, Gangahar C, Dehner LP (2018) 15q23 Gain in a neonate with a giant omphalocele and multiple co-occurring anomalies. Case Rep Pediatr 2018:8702568

32. Havalad S, Noblett H, Speidel BD (1979) Familial occurrence of omphalocele suggesting sex-linked inheritance. Arch Dis Child 54:142-151

33. Ogata T, Kagami M (2016) Kagami-Ogata syndrome: a clinically recognizable upd(14)pat and related disorder affecting the chromosome $14 \mathrm{q} 32.2$ imprinted region. J Hum Genet 61:87-94

34. Smith NM, Chambers HM, Furness ME, Haan EA (1992) The OEIS complex (omphalocele-exstrophy-imperforate anus-spinal defects): recurrence in sibs. J Med Genet 29:730-732

35. Swarray-Deen A, Seffah JD, Antwi-Agyei DA (2017) Two cases of pentalogy of Cantrell diagnosed antenatally at Korle Bu Teaching Hospital, Accra. Ghana Med J 51:191-195

36. Bastaki F, Saif F, Al Ali MT, Hamzeh AR (2016) Molecular and clinical characterization of a nonsense CDKN1C mutation in an Emirati patient with Beckwith-Wiedemann syndrome. Saudi Med J 37:215-216

37. Chen B, Chen L, Zhou Y, Mi T, Chen DY, Chen L, Yin J, Xue ZF (2013) Multiple abnormalities due to a nonsense mutation in the Alx4 gene. Genet Mol Res 12:2771-2778

38. Nichol PF, Corliss RF, Tyrrell JD, Graham B, Reeder A, Saijoh Y (2011) Conditional mutation of fibroblast growth factor receptors 1 and 2 results in an omphalocele in mice associated with disruptions in ventral body wall muscle formation. J Pediatr Surg 46:90-96

39. Tosun A, Kurtgoz S, Dursun S, Bozkurt G (2014) A case of Ehlers-Danlos syndrome type VIA with a novel PLOD1 gene mutation. Pediatr Neurol 51:566-569

40. Doi T, Puri P, Bannigan J, Thompson J (2010) Msx1 and Msx2 gene expression is downregulated in the cadmium-induced omphalocele in the chick model. J Pediatr Surg 45:1187-1191

41. Mills JL, Carter TC, Kay DM, Browne ML, Brody LC, Liu A, Romitti PA, Caggana M, Druschel CM (2012) Folate and vitamin B12-related genes and risk for omphalocele. Hum Genet 131:739-746

42. Omid AAM, Hellè M, Oumarou H, Karim CMA (2017) Abarchi Habibou Les Pathologies Chirurgicales Néonatales À I'Hôpital National De Lamordé De Niamey: Aspects diagnostiques, thérapeutiques et pronostiques. Eur Sci J 13:1857-7431

\section{Publisher's Note}

Springer Nature remains neutral with regard to jurisdictional claims in published maps and institutional affiliations. 